\title{
Human resources in artificial insemination of beef cattle: profile of managers and inseminators ${ }^{1}$
}

\section{Lívia dos Santos Russi ${ }^{2,3}$, Eliane Vianna da Costa-e-Silva ${ }^{2,4}$, Carmem Estefânia Serra Neto Zúccari2,5, Caciliana da Silva Recalde ${ }^{2,6}$}

${ }^{1}$ Suporte financeiro: FUNDECT/MS.

2 Grupo de Estudos em Reprodução Animal no Mato Grosso do Sul. GERA-MS/CNPq.

3 Programa de Pós-Graduação em Ciência Animal - FAMEZ/UFMS. Bolsista CAPES/CNPq.

${ }^{4}$ Departamento de Medicina Veterinária. Faculdade de Medicina Veterinária e Zootecnia - UFMS. Campo Grande - MS.

${ }^{5}$ Departamento de Zootecnia. Faculdade de Medicina Veterinária e Zootecnia - UFMS. Campo Grande - MS.

${ }^{6}$ Bolsista iniciação científica CNPq. Acadêmica de Medicina Veterinária FAMEZ/UFMS.

ABSTRACT - The objective of the present study was to outline the profile of managers and inseminators involved in beef cattle artificial insemination programs to characterize the management processes involved in this activity. Additionally, by interviewing managers and inseminators, it was searched to detect particularities concerned to personal life and work that can be used to evaluate the quality of life of inseminators on farms. The open questions were analyzed by frequency of answer, after being grouped by similarity. Accordingly to the results, managers associate the concept of human resource management to work supervision, mainly, prioritizing technical factors such as professional experience and indexes in the selection processes, although problems in interpersonal relationships have been shown as the main reason for dismissal. In general, education level of the inseminators is not good because most of these workers studied only to the first series of primary school. Inseminators prefer conventional artificial insemination although they recognize that fixed-time artificial insemination can make animal handling on the farm easier. The performance of these workers seems to be determined more by interpersonal relationships than by the salaries.

Key Words: beef cattle, human resources, reproductive management

\section{Recursos humanos na inseminação artificial em bovinos de corte: perfil dos administradores e inseminadores}

RESUMO - Objetivou-se delinear o perfil de administradores e inseminadores envolvidos em programas de inseminação artificial em bovinos de corte no intuito de caracterizar os processos gerenciais envolvidos nesta atividade. Adicionalmente, por meio de entrevistas com administradores e inseminadores, buscou-se detectar fatores ligados à vida pessoal e ao trabalho que possam ser utilizados como medida da qualidade de vida dos inseminadores nas propriedades rurais. As questões abertas foram analisadas por frequência de respostas, depois de agrupadas por similaridade. De acordo com os resultados, os administradores associam o conceito de gestão de recursos humanos principalmente à supervisão do trabalho priorizando fatores técnicos como experiência profissional e índices nos processos de seleção, embora apontem os problemas de relacionamento interpessoal como principal motivo de demissão. Em geral, a escolaridade dos inseminadores é precária, pois a maioria desses trabalhadores possui apenas as séries iniciais do ensino fundamental. Os inseminadores preferem a inseminação convencional, embora reconheçam que a inseminação em tempo fixo facilita o manejo na fazenda. O desempenho destes profissionais parece ser determinado muito mais pelo relacionamento interpessoal que pelo salário.

Palavras-chave: gado de corte, manejo reprodutivo, recursos humanos

\section{Introduction}

The concept of human resources refers to the administrative function of acquiring, training, assessing and remunerating workers (Dessler, 1998). Although their benefits are already well known in the urban environment, the technique is still little used in rural companies especially in the area of artificial insemination in which the selection processes do not follow well defined criteria and are often influenced by the experience and individual values of the assessors.

It is known that the inseminator is fundamental for the efficiency of the technique and that the lack of skill of this professional can limit the obtaining of satisfactory results. 
Imperfections in handling the semen (Pfeifer et al., 2009) and performing the technique and even the human-animal interaction during the procedure can affect the success of the reproductive process, so there is an urgent need for better assessment of the selection process of these professionals.

The alternatives for improving this process include the option of working with interviews to trace a professional profile, so that the individual could be placed in the function that was most suitable to his personal characteristics. This methodology came from the theory by Ajzen \& Fishbein (1980), in which the personal characteristics determine the attitudes in relation to other people and the animals, which can influence the productive process (Waiblinger et al., 2002).

Quality of life measurements can also be used to monitor the satisfaction of the individual in the work environment. They include the Inventory of Stress Symptoms in Adults, proposed by Lipp (2000), which is based on the theory that stress can be categorized in levels (alert, resistance and exhaustion phases) via physical and psychological symptomology, which can be observed and analyzed, depending on the frequency and relationship among the symptoms.

Thus the objective of this study was to trace the profile of managers and inseminators in beef cattle artificial insemination programs to characterize the management processes involved in this activity. Factors linked to the personal life and work, which could be used to assess the quality of life of the inseminators on farms, were also detected.

\section{Material and Methods}

Forty professionals in charge for the selection and training of inseminators on private beef cattle farms in the five regions of Brazil were interviewed. Each technician managed four to six farms, all with beef cattle reproduction activities and artificial insemination programs implanted. The study was carried out from November 2006 to March 2007. The script used in the interviews included questions on profession, time since professional training (time since graduation), time of working with artificial insemination/ fixed-time artificial insemination, number of inseminators/ farm, number of cows/lot suggested for fixed-time artificial insemination and the number of updating courses that the professional took per year. In addition, the interviewees were questioned on concepts linked to human resource management such as the criteria used in selecting and dismissing of inseminators, characteristics of the good inseminator, factors supervised in the AI/FTAI process, factors that could interfere in the inseminator performance, profile of the good manager, offer and encouragement to take updating courses.

In addition, questionnaires were applied to 30 inseminators from three farms located in the southeastern and mid-western Brazil, all of them with extensive beef cattle raising systems, from January to March 2007.

The applied script was developed with the help of psychologists and tested in a pre-experimental phase to verify its efficiency to obtain information that could be used to trace the profile of these professionals. The interviews were individual, taken in a location reserved for this purpose, on each farm, so that the privacy of the information obtained was maintained.

First, the objective of the interview was explained to each participant and in the case of doubt, further explanations were given and the inseminator was left to decide whether to participate or not. If he agreed, the participant would be instructed to read and fill in a term of consent, elaborated according to the norms recommended by the Comitê de Ética em Experimentação Humana da Universidade Federal de Mato Grosso do Sul to permit the use of the data from the interviews.

In the used script, the questions were divided into four large groups. The first, called "personal data” included questions on gender, age, marital status, number of children, position/job, education level, satisfaction with housing (yes or no) and desire to alter the house (yes or no).

The second group, called "social life", included questions on the possibility of leave on weekends (yes or no), type of leisure activities (individual or collective) and religious belief (yes or no). Individual activities were considered to be those that the individual could do alone, such as watching television, and collective activities were considered to be those that the individual do in groups, such as football matches.

The third group, called "health", dealt with questions on medical and dental assistance subsidized by the farm, use of medication, accidents resulting from working with the animals and sleep quality, all with the binomial-type response (yes or no).

The fourth group, called "professional”, included questions related to professional experience such as the age they started to work, time of working in the company, insemination and updating courses (yes or no). Questions dealing with satisfaction with the current wages (yes or no), characteristics of a good inseminator, factors that could interfere with the work, type of artificial insemination that was considered the best (conventional artificial 
insemination or fixed-time artificial insemination), knowledge of rational management and interest in taking new courses (both with the possibility of the binomial-type response) were also taken.

The last group also contained a question regarding plans for the future, which were classified as individual or collective, according to the type of response. Individual plans were considered to be those for the individual alone, such as getting a better job, and collective plans to be those for third parties, such as buying a house for the family or ensuring the education of the children.

After finishing the questionnaire, the participant was instructed to answer by himself the Inventário de Sintomas de Stress para Adultos (Inventory of Stress Symptoms in Adults) - ISSL - where he marked if he had any of the symptoms described. The ISSL was read and explained to each participant before being answered. All the answer sheets were marked with numerical codes only for data control and there was no nominal identification of the participants.

For statistical analysis, the managers were grouped into classes, constructed in function of time since professional training ( $\mathrm{CtF}$ ) accordingly to the Yule frequency distribution model proposed by Sampaio (1998). Spearman correlation analyses and analyses of variance were performed considering the fixed effect of the $\mathrm{CtF}$ on the quantitative variables, and the means were compared by the Duncan's test. The open questions were analyzed by frequency of the answers, after grouping by similarity. The data of the inseminators were also analyzed by frequency of the answers, after grouping for similarity and Spearman correlation analyses. All the analyses were made using the SAS Statistics Program (SAS, 1999) at 5\% level of significance.

\section{Results and Discussion}

Out of all the interviewed managers, thirty-five were graduated in Veterinary Medicine, three in Animal Science, and two in technical courses in agriculture or surveying, and most of them worked in the Mid-West region of Brazil
(60\%), followed by the Southeast (17\%), South (11\%), Northeast (7\%) and North (4\%) regions. These regional differences may be important in determining the management profile because not only individual values but also cultural values can interfere in the practices adopted in human resource management and even in the acceptance of new techniques (Stone et al., 2007).

The average time since professional training was $11.15 \pm 7.29$ years $(\mathrm{CV}=65.39)$ and the time working with fixed-time artificial insemination was $10.20 \pm 6.98$ years $(\mathrm{CV}=68.40)$. On average, the managers managed $1.63 \pm 0.96$ inseminators per farm (CV = 59.02), indicating $137.00 \pm 76.00$ females/lot in fixed-time artificial insemination (CV = 55.47) and taking $1.49 \pm 1.22$ professional updating courses a year $(\mathrm{CV}=81.80)$.

Positive correlations were found between the class of time since professional training and time working with artificial insemination $\left(\mathrm{P}<0.0001 ; \mathrm{r}_{\mathrm{s}}=0.86\right)$, thus the greater the number of the classes, the longer the working time of the professional. Indeed, it was found a correlation between the time since professional training and the time of working with artificial insemination $\left(\mathrm{P}<0.0001 ; \mathrm{r}_{\mathrm{s}}=0.88\right)$, which indicated that the professionals that act in this area begin working with insemination soon after graduation.

In the analysis of variance, the class of time since professional training influenced the graduated time $\left(\mathrm{P}<0.0001 ; \mathrm{r}^{2}=0.93 ; \mathrm{CV}=18.05\right)$ and the time working with artificial insemination $\left(\mathrm{P}<0.0001 ; \mathrm{r}^{2}=0.82 ; \mathrm{CV}=30.78\right)$. The time since professional training did not alter the characteristics of management (Table 1).

Considering the questions on human resource management, $60 \%$ of the interviewees (24/40) stated that they adopted some type of the management technique on the farms where they worked. However, 71\% (17/24) had difficulty in conceptualizing it, consequently, there was a great variation in the responses (Figure 1) and an incorrect association between the concept of management and that of technical following of the work (production management) was observed, suggesting that the managers might not visualize human resource management as a global process

Table 1 - Determinant professional characteristics of the selection processes and management of inseminators in Brazil, regarding the class of time since training

\begin{tabular}{|c|c|c|c|c|c|}
\hline & \multicolumn{5}{|c|}{ Class of time since professional training } \\
\hline & 2 - 7 years & 7 - 12 years & 12 - 17 years & 17 - 22 years & 22 - 27 years \\
\hline Time since professional training (years) & $3.86 \pm 1.70 \mathrm{e}$ & $9.60 \pm 1.43 \mathrm{~d}$ & $14.29 \pm 1.25 c$ & $18.50 \pm 0.58 b$ & $24.40 \pm 4.33 a$ \\
\hline Time working with AI/FTAI (years) & $4.43 \pm 3.16 \mathrm{~d}$ & $8.30 \pm 2.58 c$ & $11.29 \pm 3.90 \mathrm{c}$ & $16.75 \pm 2.87 \mathrm{~b}$ & $23.40 \pm 3.13 a$ \\
\hline Number of inseminators /farm & $1.46 \pm 1.06 \mathrm{a}$ & $1.70 \pm 0.79 a$ & $1.71 \pm 1.50 \mathrm{a}$ & $1.63 \pm 0.48 \mathrm{a}$ & $1.80 \pm 0.45 a$ \\
\hline Number of cows/lot suggested for FTAI & $107.14 \pm 66.53 a$ & $153.00 \pm 47.03 a$ & $189.29 \pm 125.71 \mathrm{a}$ & $125.00 \pm 50.00 \mathrm{a}$ & $125.00 \pm 50.00 \mathrm{a}$ \\
\hline Number of updating courses/year & $1.64 \pm 1.60 \mathrm{a}$ & $1.50 \pm 1.43 a$ & $1.29 \pm 0.49 a$ & $1.88 \pm 0.25 a$ & $1.00 \pm 0.71 \mathrm{a}$ \\
\hline
\end{tabular}

Different lowercase letters on the same line indicate difference $(\mathrm{P}<0.05)$ by the Duncan's test. 
in which their responsibilities would be much wider and would go beyond the simple selection and integration of new workers. In this process, it should be also included team training, stimulation of creative cooperation, and establishment of agreeable relations at work, cost control, development of the abilities of the individuals and skills, health protection and creation of suitable work conditions (Clarke et al., 2006).

The managers seemed to prefer to use factors such as experience and indexes (Figure 2) and they paid little attention to psychological based criteria, such as good interpersonal relationships. This may have occurred because of the evaluation easiness of the technical criteria and the selective process used itself, which generally consists of assessing previous references or choosing local workers to take on the job of inseminator. The psychological based criteria require a more detailed selective process and often this aspect is really known only in the daily life of the farm.

A large number of inseminators are dismissed because of interpersonal relationship problems (Figure 3), a criterion little used in the selection process. Similar results were obtained by Billikopf (2001) in a study with 42 managers in California (USA), in which insubordination (26\%) and aggressive temperament (17\%) were shown to be the main reasons for dismissal, suggesting that, regardless of the technological level used on the farm, the psychological criteria are an important factor.

In the group of managers that selected workers by observing their interpersonal relationships (5/40), only $20 \%(1 / 5)$ dismissed for that reason. In the group that did not select (35/40), 77\% (27/35) dismissed workers for this reason, showing how efficient this assessment can be when hiring new workers.

Among the factors that can harm the inseminator performance (Figure 4), satisfaction in the work environment was mentioned by most of the interviewees, corroborating the findings by Fernandes Jr. (2001), who demonstrated the

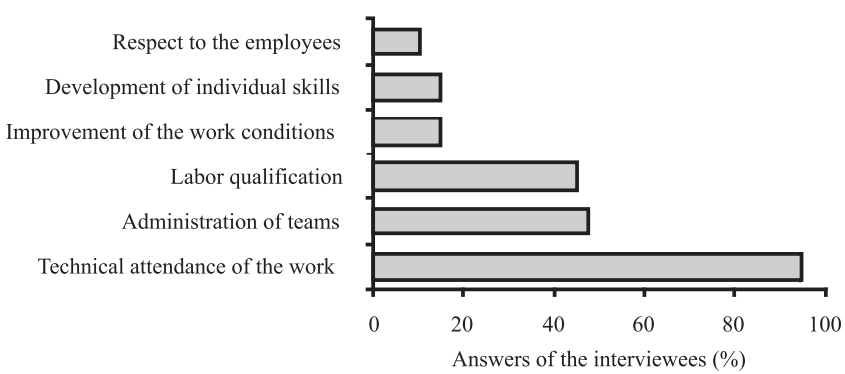

Figure 1 - Main concepts associated to human resource management, according to managers of beef cattle artificial insemination programs in Brazil $(n=40)$.

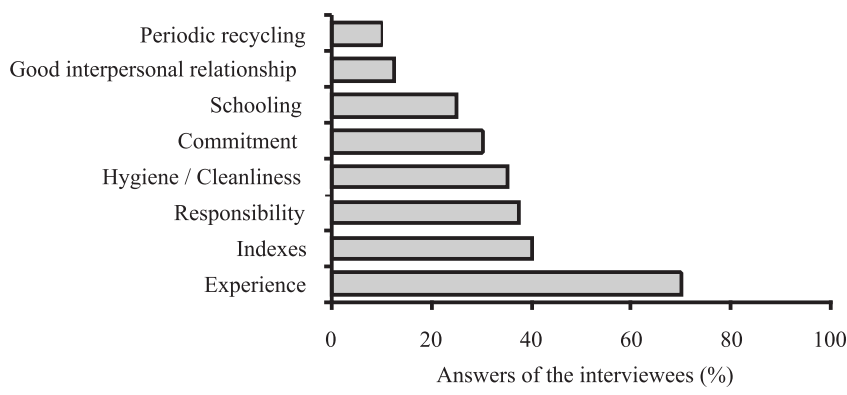

Figure 2 - Criteria for selection of inseminators, according to managers of beef cattle artificial insemination programs in Brazil $(n=40)$.

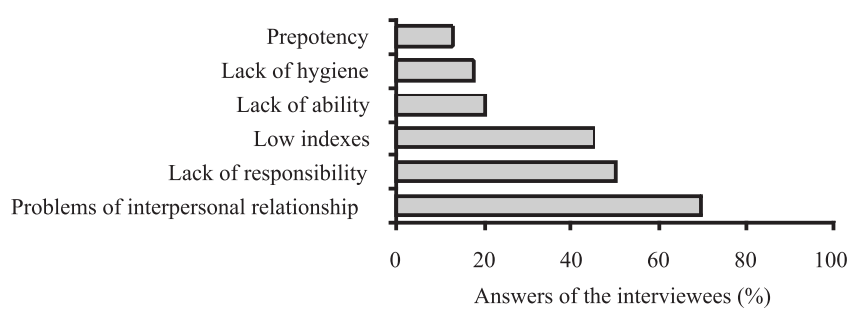

Figure 3 - Reason for dismissing inseminators, according to managers of beef cattle artificial insemination programs in Brazil ( $\mathrm{n}=40)$.

importance of this criterion for the success of artificial insemination programs, suggesting that satisfied inseminators presented better results.

In the study by Strochlic \& Hamerschlag (2005), the inseminators were asked about the factors they most appreciated in an environment with good working conditions. The main mentioned elements, according to the frequency of the answers, were respectful treatment, tranquility to perform the work, a fair payment, stability, medical assistance, good food, a healthy and safe environment, flexible hours, opportunity for professional development, task diversity, involvement in the decision making process and retirement plans. These authors also

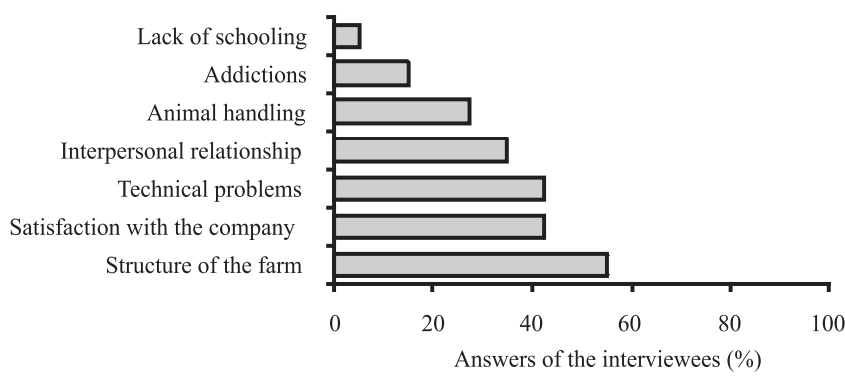

Figure 4-Factors that can harm the performance of the inseminator, according to managers of beef cattle artificial insemination programs in Brazil $(n=40)$. 
reported that the workers expressed appreciation for apparently simple, but often forgotten, gestures in the daily activities such as greetings, inquiring about the family, sharing meals or invitations to celebrations.

Several studies have shown other factors that can impair the efficiency of the inseminator especially emotional state (Cembrowicz, 1964 quoted by Pickett, 1971), confidence in the semen batch (Uwland, 1983), safety regarding positioning the pipette and the place of semen deposit (Stevenson, 2005), the type of inseminator (Schermerhorn et al., 1986 quoted by Buckley et al., 2003) and updating (Senger et al., 1988), however, they were not mentioned by the interviwed technicians.

Although $100 \%$ of the managers stated that they encouraged workers to take updating courses, only $47 \%$ made these courses available on the farms, which can make professional training difficult. Recycling is a very important factor for the efficiency of the inseminator, because it makes him more interested in the processes used in artificial insemination, increasing his skills and self confidence (King \& MacPherson, 1965). Peters et al. (1984) showed by $\mathrm{X}$-rays that approximately one-third of the inseminators placed the semen inside the cervix, showing the need for training. Fernandes Jr. (2001) observed that skills $(\mathrm{P}<0.01)$ and taking artificial insemination $(\mathrm{P}<0.05)$ and recycling $(\mathrm{P}<0.01)$ courses generated differences among inseminators in the pregnancy rate at the first artificial insemination.

Even though all the managers (100\%) stated that they instructed the workers on how to manage the animals, only $35 \%(14 / 40)$ assessed animal management during the execution of the artificial insemination (Figure 5). This result generates a problem because the stress caused by improper management can impair GnRH release, the luteinizant hormone and estrogens, by harming follicular development and impairing the maintenance of normal oestrus cycles (Varley \& Stedman, 1994; MacFarlane et al., 2000). In addition, it can decrease the expression of oestrus,

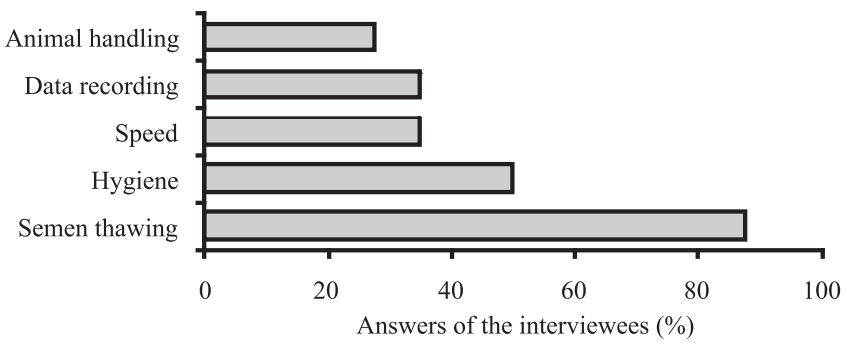

Figure 5 - Factors supervised during insemination, according to managers of beef cattle artificial insemination programs in Brazil $(n=40)$. delay ovulation and it can cause embryonic losses (Dobson \& Smith, 2000).

Differences between working with professional inseminators and those on the farm were reported by about $80 \%$ of the managers (31/40). Many managers $(71 \%, 22 / 31)$ preferred to work with inseminators from the farm because these workers knew the farm, the management routine and the other workers better. The remaining 29\% (9/31) preferred professional inseminators and explained that because of a greater training, they obtained better results. Only 22.5\% $(9 / 40)$ of the managers stated there were no differences between the two types.

Regarding the managers, 75\% (30/40) said they gave some kind of award or financial incentive when the goals were met, but only $47 \%$ (14/30) awarded prizes to the artificial insemination team, which may determine the appearance of problems in relationships because only the inseminator would be benefitted.

The importance of training and updating of the managers was observed in the question regarding knowledge of rational management. Although only 35\% (14/30) had taken part in some training on the subject, 79\% (11/14) believed that improper management can damage the results of the artificial insemination program, so that $57 \%$ (8/14) assessed management during the execution of the procedures.

The following characteristics associated with the good inseminator were mentioned: responsibility (52.5\%), dedication (42.5\%), patience (40\%), experience (40\%), hygiene (30\%) and attention (15\%). Only 27.5\% mentioned the ability to work in a group. This suggested that the managers associated the good results of artificial insemination to individual factors, inherent to each inseminator, and this could justify the fact that awards were given only to this professional.

In the description of the profile of a good manager, the main characteristics mentioned were ability to maintain good relationships with the workers (67.5\%), empathy (35\%), commitment to the company (32.5\%), technical knowledge (27.5\%), leadership (27.5\%) and creativity (7.5\%). These findings were confirmed by the characteristics given to the bad manager, which were authoritarianism (50\%), lack of commitment (40\%), poor interpersonal relationships (35\%), lack of technical knowledge (27.5\%) and dishonesty(20\%).

All the assessed inseminators (30 professionals) were at an average age of $35.23 \pm 10.42$ years old $(\mathrm{CV}=29.57)$, and they had $1.77 \pm 1.30$ children/family $(\mathrm{CV}=73.85)$. They began working at $13.00 \pm 3.48$ years of age $(\mathrm{CV}=26.80)$ and had worked for $9.24 \pm 8.11$ years $(C V=87.75)$ in the company. All 
were male (30/30), 83.3\% (25/30) were married and 60\% $(18 / 30)$ stated that they practiced some religion.

Age correlated positively with the number of children $\left(\mathrm{P}<0.01 ; \mathrm{r}_{\mathrm{s}}=0.48\right)$, religion practicing $\left(\mathrm{P}<0.05 ; \mathrm{r}_{\mathrm{s}}=0.39\right)$, time working in the company $\left(\mathrm{P}<0.01 ; \mathrm{r}_{\mathrm{s}}=0.48\right)$ and the use of medication $\left(\mathrm{P}<0.05 ; \mathrm{r}_{\mathrm{s}}=0.40\right)$ and it correlated negatively to sleep quality $\left(\mathrm{P}<0.05 ; \mathrm{r}_{\mathrm{s}}=-0.47\right)$.

Satisfaction with housing was negatively correlated with the desire to alter the house $\left(\mathrm{P}<0.01 ; \mathrm{r}_{\mathrm{s}}=-0.68\right)$ and positively correlated to sleep quality $\left(\mathrm{P}<0.05 ; \mathrm{r}_{\mathrm{s}}=0.52\right)$ and to participation in collective leisure activities $(\mathrm{P}<0.05$; $\left.r_{s}=0.50\right)$. This suggested that the farms with a better quality of life had places for the workers to have leisure activities during leave, allowing a better use of free time and encouraging social interaction.

Taking an artificial insemination course was positively correlated with updatings $\left(\mathrm{P}<0.0001 ; \mathrm{r}_{\mathrm{s}}=0.65\right)$, knowledge of rational management $\left(\mathrm{P}<0.05 ; \mathrm{r}_{\mathrm{s}}=0.46\right)$, interest in taking new courses $\left(\mathrm{P}<0.05 ; \mathrm{r}_{\mathrm{s}}=0.45\right)$ and wages $(\mathrm{P}<0.05$; $\left.r_{s}=0.51\right)$. These findings suggested that the opportunity for professional training can be important to increase the desire for continuous improvement by the workers and for increasing their income.

The level of education was positively related to the position $\left(\mathrm{P}<0.01 ; \mathrm{r}_{\mathrm{S}}=0.46\right)$ and to plans for the future $\left(\mathrm{P}<0.05 ; \mathrm{r}_{\mathrm{s}}=0.51\right)$, so that the inseminator with a greater level of schooling generally occupied higher hierarchical positions on the farm and made collective plans, that is, involved third parties, such as acquiring a house and investing in the education of their children.

In the education level distribution, primary education (from $1^{\text {st }}$ to $8^{\text {th }}$ grade) was divided into two groups to make the representation of the results in the graph easier: the first grades of primary school ( $1^{\text {st }}$ to $4^{\text {th }}$ grades $)$ and the last grades ( $5^{\text {th }}$ to $8^{\text {th }}$ grades). The high school courses (agricultural technician and surveyor) were grouped as technical courses.

Most of the inseminators (43.3\%; 13/30) studied only to the first primary grades, usually not completed, which showed precarious schooling among these workers (Figure 6). This can be explained by the difficulty of access to schools in rural districts and also because they started working very young, which could have contributed to quiting school at the first grades.

In the assessment on the health of the inseminators, $67 \%(20 / 30)$ stated they had medical and dental assistance paid by the farm and $60 \%(18 / 30)$ had already suffered some serious accident while managing the animals. Regarding the professional information, out of the $87 \%$
(26/30) that had taken an artificial insemination course, $73 \%(19 / 26)$ had also taken updating courses in the last two years. Furthermore, 60\% (18/30) stated that they did not know rational management techniques and $87 \%(26 / 30)$ showed interest in taking new courses.

Among the inseminators, 56.7\% (17/30) preferred conventional artificial insemination, 40\% (12/30) preferred fixed-time artificial insemination and only 3.3\% (1/30) stated they did not notice differences between them. This preference may be explained by the fact that although $38.7 \%(12 / 30)$ of the interviewees stated that fixed-time artificial insemination can facilitate management on the farm, 29\% (9/30) believed that the technique itself produces worse results. They considered as negative factors that it is not a natural procedure because the oestrus is not observed (19.4\%) and the animal stress is greater because they are taken several times to the corral (12.9\%).

The main characteristics associated to the good inseminators were patience (69\%), attention (41.4\%), good interpersonal relationships (38\%), liking the work (27.6\%), desire to learn (17\%), hygiene (14\%) and experience (7\%). For the factors that could damage performance, 83\% mentioned work colleagues, $52 \%$ the problems related to the farm structure (chutes, pasture availability), 28\% the quality and nutritional state of the animals and 3.5\% the semen. Surprisingly, payment was mentioned by only $34.5 \%$, suggesting that the quality of interpersonal relationships may be more important than low wages in determining the results of the inseminators. This result is understandable because the interviewees live on the farms and form a society within them so that living with the other workers is constant and therefore can damage performance in the work environment.

None of the inseminators was beyond the alert phase, based on Inventário de Sintomas de Stress para Adultos (Inventory of Stress Symptoms in Adults) -ISSL - which

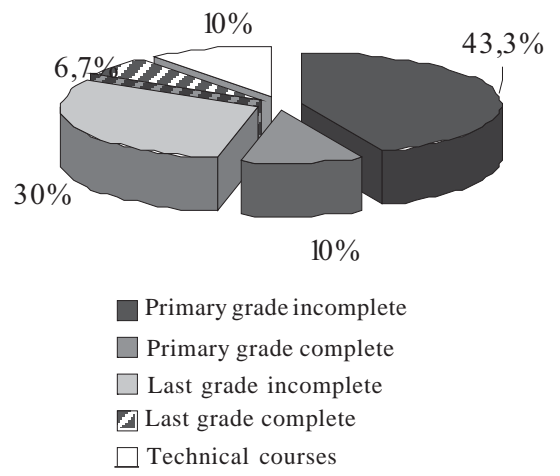

Figure 6 - Level of schooling of inseminators working in beef cattle raising in Central Brazil $(n=30)$. 
is a good result because this is the positive phase of stress, characterized by adrenalin production and action that makes the individual more attentive, strong and motivated (Lipp, 2000). However, if this phase is maintained for very long periods or if new stressors accumulate, the organism could enter into the resistance phase, when it tries to reestablish the homeostasis damaged in the initial phase. Thus, productivity begins to be affected and the individual may become more susceptible to disease.

This observation corroborates the findings of the inventory about the symptoms most frequently mentioned, in which physical symptoms predominated compared to psychological symptoms. The physical problems included muscular tension/tiredness (21\%), stomach pains (18\%), changes in appetite (14\%), high blood pressure (6.5\%) and insomnia (5\%). The psychological symptoms included the sudden desire to start new projects (13\%), loss of sense of humor (6.5\%), constant thoughts on one subject (5\%), daily anxiety and prolonged apathy (3\%).

\section{Conclusions}

The managers in charge of artificial insemination programs associate the concept of human resource management mainly to work supervision, prioritizing technical factors in the selection processes although they indicate the problems in interpersonal relationships as the main reason for dismissal. Interpersonal relationships can be more important than the wages in determining the performance of the inseminator. New studies should be carried out to broaden this information and permit the development of guidelines that can help in the management of inseminators for beef cattle raising.

\section{Acknowledgments}

The authors thank FUNDECT-MS for financial support; CAPES for the MSC grant, Professor Diva Lopes da Silveira for help in elaborating the questionnaires and the farms, for supplying the other information necessary for the research.

\section{References}

AJZEN, I.; FISHBEIN, M. Understanding attitudes and predicting social behaviour. Englewood Cliffs, NJ: Prentice-Hall, 1980. 278p.

BILLIKOPF, G.E. Interpersonal communication tops concerning farm supervisors. California Agriculture, v.55, n.5, p.40-43, 2001.

BUCKLEY, F.; MEE, J.; O'SULLIVAN, K. et al. Insemination factors affecting conception rate in seasonal calving Holstein-
Friesian cows. Reproduction Nutrition Development, v.43, p.543-555, 2003.

CLARKE, M.; ISLAM, S.M.N.; PAECH, S. Measuring Australia's well-being using hierarchical needs. Journal of SocioEconomics, v.35, p.933-945, 2006.

DESSLER, G. Management, leading people e organizations in the 21 century. Upper Saddle River, NJ: Prentice Hall, 1998. 282p.

DOBSON, H.; SMITH, R.F. What is stress and how does it affect reproduction? Animal Reproduction Science, v.60-61, p.743-752, 2000.

FERNANDES JR., J.A. Inseminação artificial em gado de corte: impacto da equipe de inseminadores nos resultados obtidos. 2001. 87f. Dissertação (Mestrado em Medicina Veterinária) - Faculdade de Ciências Agrárias e Veterinárias/ Universidade Estadual Paulista, Jaboticabal.

KING, G.J.; MACPHERSON, J.W. Observations on retraining of artificial insemination technicians and its importance in maintaining efficiency. Canadian Veterinary Journal, v.6, p.83-87, 1965.

LIPP, M.E.N. Manual do inventário de sintomas de stress para adultos (ISSL). São Paulo: Casa do Psicólogo, 2000. 55p.

MACFARLANE, M.S., BREEN; K.M., SAKURAI; H. et al. Effect of duration of infusion stress-like concentrations of cortisol on follicular development and the pre-ovulatory surge of LH in sheep. Animal Reproduction Science, v.63, p.167-175, 2000.

PETERS, J.L.; SENGER, P.L.; ROSENBERGER, J.L. et al. Radiographic evaluation of bovine artificial inseminating technique among professional and herdsman-inseminators using .5 and .25-ml French straws. Journal of Animal Science, v.59, n.6 p.1671-1683, 1984.

PFEIFER, L.F.M.; CASTILHO, E.M.; ROLL, V.F.B. et al. Efeito da duração do tratamento com progestágeno e da maturidade sexual na taxa de prenhez em novilhas de corte: avaliação econômica e biológica. Revista Brasileira de Zootecnia, v.38, n.7, p.1205-1210, 2009.

PICKETT, B.W. Factors affecting the utilization of frozen bovine semen. The A.I. Digest, v.19, n.2, p.8-24, 1971.

SAMPAIO, I.B.M. Estatística aplicada à experimentação animal. Belo Horizonte: Fundação de Ensino e Pesquisa em Medicina Veterinária, 1998. 221p.

SENGER, P.L.; BECKER, W.C.; DAVIDGE, S.T. et al. Influence of cornual insemination on conception rates in dairy cattle. Journal of Animal Science, v.66, p.3010-3016, 1988.

STATISTICAL ANALYSIS SYSTEM - SAS. User's guide: Stat, version 8. Cary, NC: SAS Institute Inc., 1999. 3809p.

STEVENSON, J.S. Factors to improve pregnancy rates in lactating dairy cattle. In: CONGRESSO BRASILEIRO DE REPRODUÇÃO ANIMAL, 16., 2005, Goiânia. Anais... Goiânia: Colégio Brasileiro de Reprodução Animal, [2005]. (CD-ROM).

STONE, D.L.; STONE-ROMERO, E.F.; LUKASZEWSKI, K.M. The impact of cultural values on the acceptance and effectiveness of human resource management policies and practices. Human Resource Management Review, v.17, p.152-165, 2007.

STROCHLIC, R.; HAMERSCHLAG, K. Best labor management practices on twelve California farms: toward a more sustainable food system, California: California Institute for Rural Studies, 2005. 28p.

UWLAND, J. Influence of technicians on conception rates in artificial insemination. Theriogenology, v.20, n.6, p.693-697, 1983.

VARLEY, M.; STEDMAN, R. Stress and reproduction. In: COLE, D.J.A.; WEISSMAN, J.; VARLEY, M.A. (Eds.). Principles of pig science. Nottingham, UK: Nottingham University Press, 1994. p.227-297.

WAIBLINGER, S.; MENKE, C.; COLEMAN, G. The relationship between attitudes, personal characteristics and behaviour of stockpeople and subsequent behaviour and production of dairy cows. Applied Animal Behaviour Science, v.79, p.195-219, 2002. 